\title{
Web-Enhanced Teaching and Learning Vehicle Preference in Landscape Architecture Construction Studio Courses
}

\author{
Young-Jae Kim ${ }^{1}$, Jun-Hyun $\mathrm{Kim}^{2}$ and Ming-Han $\mathrm{Li}^{3}$ \\ ${ }^{1,2,3}$ Texas A\&M University, College Station, United States
}

Correspondence should be addressed to: Young-Jae Kim; youngjaekim0603@gmail.com

Received date: 22 September 2014; Accepted date: 20 December 2014; Published date: 17 September 2015

Academic Editor: George Kostopoulos

Copyright @ 2015. Young-Jae Kim, Jun-Hyun Kim and Ming-Han Li. Distributed under Creative Commons CCBY 4.0

\begin{abstract}
Web-enhanced teaching has been widely utilized in many disciplines in US higher education since the development of the internet and the continuous advancement of information technology. The purpose of this study is to investigate the learning effectiveness of web-enhanced teaching in landscape construction studio courses and compare students' preference in different learning vehicles between the 2003-2004 and 2011-2012 surveys.The satisfaction level with web-enhanced teaching increased to $95 \%$ in the $2011-2012$ investigation, compared to $73 \%-87 \%$ in the 2003 2004 one. Further, in the 2011-2012 study, more graduate students reported that their learning would be worse without web-enhanced teaching than undergraduates. The two surveys (2003-04 and 2011-12) on preferred learning vehicles yielded a similar result: online lectures were highly preferred by graduate students, while help from instructors in the studio and help from classmates were highly preferred by undergraduates. Further, students expecting an A grade preferred individual learning whereas students expecting a B or C grade relied on interactive learning methods. This study provides landscape architecture instructors with an insight into the opportunities and challenges of implementing web-enhanced teaching in studio-based courses. Particularly, lessons learned from both studies are summarized for those who may use a similar pedagogical approach.
\end{abstract}

Keywords: Web-enhanced teaching, landscape construction studio course, studio-based learning, online education

\section{Introduction}

Web-enhanced teaching has been widely utilized in many disciplines in higher education since the development of the internet and the continuous advancement of information technology (IT) (Scanlon et al., 2000). The roles of the internet and IT have quickly changed from a subordinate function to an essential element in the classroom, enhancing the learning process (Benbunan-Fich, 2002). For example, students with special needs or difficulties in getting to school for some reason, such as illness or unexpected accidents, can benefit from web-enhanced teaching because it can provide the students with distant learning

Cite this Article as: Young-Jae Kim, Jun-Hyun Kim and Ming-Han Li (2015)," Web-Enhanced Teaching and Learning Vehicle Preference in Landscape Architecture Construction Studio Courses ", Journal of e-Learning and Higher Education, Vol. 2015 (2015), Article ID 511323, DOI: 10.5171/2015.511323 
activities that allow them to access course content and materials at anytime and anywhere (Salomoni and Mirri, 2004). Further, web-based tools using IT are effective in developing systematic teaching materials and reducing the workload of instructors (Chang et al., 2006).

The internet and IT have also improved the pedagogical aspects in students' learning experiences in the design studio (Matthews and Weigand, 2001). The positive influence of the web-enhanced teaching method on design education has been described by three factors: 1) fast information exchange (saving time), 2) distance interaction and communication, and 3) efficient learning and presentation (Chen and You, 2010). However, a concern about webenhanced or web-based teaching in studio courses can be raised with respect to decreased face-to-face interactivity that is a key component in studio or classroom learning ( $\mathrm{Li}$, 2007). In landscape architecture studio teaching, interactivity has been regarded as one of the most important pedagogical components. Therefore, web-enhanced teaching's positive gain and its negative loss in interactivity should be carefully balanced. As a form of education, web-enhanced method has been devised to enhance students' learning experiences in a design studio-based course, which combines traditional face-to-face instruction with webenhanced teaching (Jonasson, 1997, Abrams and Haefner, 2002). In a web-enhanced studio course, students and instructors are present at the same time during the face-to-face session and continue to communicate outside of the class through e-learning. Bender and Vredevoogd (2006) reported that blended learning in delivering course materials and facilitating group work, which combines personal interaction with online education, were positively related to students' enhanced learning experiences. In another study comparing the effectiveness between webbased and web-enhanced teaching, it was found that web-enhanced teaching produced a better success rate in achieving students' learning as well as contributing to a lower course dropout rate than the web-based one (Dziuban and Moskal, 2001). Li (2007) also reported that web-enhanced teaching was a valuable source in landscape architecture studio-based courses, and undergraduate students preferred different types of learning vehicles compared to graduate students. Since IT has been continuously improved and students' accessibility and familiarity with IT products has also been improved, the roles of web-enhanced teaching in enhancing students' learning might have changed in recent years. Hence, it is meaningful to investigate the effectiveness of webenhanced teaching, and to examine the trend of learning vehicles preferred in studio-based courses between the past and the present.

The researchers conducted a longitudinal comparison on two investigations that were eight years apart (the first one in 2003-04 and the second in 2011-2012) with the following specific purposes: 1) evaluation of students' learning satisfaction and the effectiveness of elearning in landscape architecture construction studio courses, 2) comparison of trends in learning vehicles preferred by graduate and undergraduate students, and 3) examination of preferred learning vehicles between students expecting an A grade and those expecting a B or $\mathrm{C}$ grade.

\section{Methods}

\section{Study Samples and Data}

This study is a follow-up investigation for a study conducted in 2003-2004 in assessing the effectiveness of students' learning in a webenhanced landscape construction studio course by Li (2007). In this study, assessment data were collected by survey instruments for a total of 45 undergraduate and 26 graduate students enrolled in landscape construction studio courses at Texas A\&M University during 2011 and 2012. The survey focused on students' perceived satisfaction and preferences for several learning methods, including webenhanced teaching and traditional face-to-face methods (Table 1). A total of eight items were measured in the 2003-2004 survey and ten items were measured in the 2011-2012 survey. In each semester, students were asked to respond to two similar surveys regarding their learning experiences. The first survey was conducted right after the midterm exam and the second one was asked on the last day of the semester. In both surveys, students ranked learning vehicles in terms of learning effectiveness. Further, students evaluated their learning satisfaction with web-enhanced teaching in both surveys. 
IBIMA Publishing

Journal of e-Learning and Higher Education

http://www.ibimapublishing.com/journals/JELHE/jelhe.html

Vol. 2015 (2015), Article ID 511323, 8 pages

DOI: $10.5171 / 2015.511323$

Table 1: Learning Vehicles used in the 2003-2004 and 2011-2012 Studies

\begin{tabular}{|l|c|c|}
\hline Learning vehicles & $\begin{array}{c}2003-2004 \text { study } \\
\text { (Eight items) }\end{array}$ & $\begin{array}{c}\text { 2011 - 2012 study } \\
\text { (Ten items) }\end{array}$ \\
\hline WebCT vista online lectures & $\sqrt{ }$ \\
\hline In-class supplemental lectures & $\sqrt{ }$ \\
\hline In-class lectures using Powerpoint slides & $\sqrt{ }$ \\
\hline In-class exercise /practical exam feedback & $\sqrt{ }$ \\
\hline Help from instructors in the studio & $\sqrt{ }$ \\
\hline Help from classmates & $\sqrt{ }$ & $\sqrt{ }$ \\
\hline Working on homework assignments & $\sqrt{ }$ \\
\hline Working on exercise assignments & $\sqrt{ }$ \\
\hline Working on in-class assignments & $\sqrt{ }$ \\
\hline Demonstration videos stored in e-learning & $\sqrt{ }$ \\
\hline Class Journal & $\sqrt{ }$ \\
\hline Reading the textbook & $\sqrt{ }$ \\
\hline
\end{tabular}

\section{Analysis Procedure}

To compare results from two investigations, as a basic step of analyses, descriptive statistics were conducted to examine the satisfaction with web-enhanced teaching and e-learning efficiency. For the analysis of the trend changes in preferred learning vehicles between two investigations (2003-2004 vs. 2011-2012 surveys), average rankings of each vehicle were compared between two groups: graduate and undergraduate students. In addition, bivariate analyses between students who expected an A grade and those expecting a $\mathrm{B}$ or $\mathrm{C}$ grade were conducted to further examine the mean differences. The hypothesis of this analysis is that students who expected a higher grade were more likely to prefer individual and webenhanced teaching while students expecting a lower grade were more likely to prefer more interactive teaching methods such as help from instructors or classmates.

\section{Results}

\section{Learning Satisfaction}

In the 2003-2004 study, the overall percentage of students satisfied with web-enhanced teaching was $73 \%$ in the first survey and it improved to $87 \%$ in the second one. In 2011 and 2012, the percentage of satisfaction was $95 \%$, significantly higher than those in the 2003-2004 study. We attribute the significant increase of satisfaction to two factors. First is the advancement of information technology that was further integrated into the 2011-2012 teaching. The 2011-2012 online course management software (i.e., Vista System) was more user friendly than the 2003-2004 version. The second factor is students' familiarity with information technology and their expectation of the use of technology in their education today.

\section{E-learning Effectiveness}

In the second survey conducted in 2011 and 2012, a new question was added to assess learning effectiveness of web-enhanced teaching. Table 2 presents the results of learning effectiveness of both undergraduates and graduates. More graduate students reported that e-learning provided a positive influence on their learning experience than undergraduate students $(92.0 \%$ for graduates vs. $70.6 \%$ for undergraduates). In contrast, more undergraduates responded that their learning would not be changed even if elearning was not utilized $(26.5 \%$ for undergraduates vs. $8.0 \%$ for graduates).

Cite this Article as: Young-Jae Kim, Jun-Hyun Kim and Ming-Han Li (2015)," Web-Enhanced Teaching and Learning Vehicle Preference in Landscape Architecture Construction Studio Courses ", Journal of e-Learning and Higher Education, Vol. 2015 (2015), Article ID 511323, DOI: 10.5171/2015.511323 
Table 2: Descriptive Statistics of E-Learning Effectiveness by Undergraduate and Graduate Students in the 2011 and 2012 Surveys

\begin{tabular}{|c|c|c|c|c|c|c|}
\hline \multirow{2}{*}{$\begin{array}{l}\text { If e-Learning is not used in } \\
\text { this course, your learning } \\
\text { may... }\end{array}$} & \multicolumn{2}{|c|}{$\begin{array}{l}\text { Undergraduate } \\
\text { students }\end{array}$} & \multicolumn{2}{|c|}{$\begin{array}{l}\text { Graduate } \\
\text { students }\end{array}$} & \multicolumn{2}{|l|}{ Total } \\
\hline & Freq. & Percent & Freq. & Percent & Freq. & Percent \\
\hline Get better & 1 & 2.9 & 0 & 0.0 & 1 & 1.7 \\
\hline Make no difference & 9 & 26.5 & 2 & 8.0 & 11 & 18.6 \\
\hline Get worse & 24 & 70.6 & 23 & 92.0 & 47 & 79.7 \\
\hline Total & 34 & 100.0 & 25 & 100.0 & 59 & 100.0 \\
\hline
\end{tabular}

Comparison of Average Rankings of Learning Vehicles between 2003-04 and 2011-12 Surveys

Table 3 shows the results of perceived learning vehicle preferences and the mean differences between undergraduate and graduate students in the 2003 and 2004 surveys. WebCT vista online lectures as one of the web-enhanced teaching methods was highly preferred by graduate students, compared to undergraduate students (a higher ranking of 2.7 by graduate students, $\mathrm{p}<0.01$ ). However, undergraduate students preferred help from instructors in the studio or from classmates. The mean difference of the ranking in preferred learning vehicles between the two groups was statistically significant at the 0.05 level (a higher ranking of 1.2 for help from instructors, and a higher ranking of 1.0 for help from classmates by undergraduate students). The other five items for the learning vehicles did not show statistically significant relationships between two groups.

Table 3: Descriptive Statistics and Bivariate Analyses of Learning Vehicle Rankings between Undergraduate and Graduate Students in the 2003 and 2004 Surveys

\begin{tabular}{|c|c|c|c|c|c|c|c|c|c|}
\hline \multirow{3}{*}{ Learning vehicles } & \multicolumn{3}{|c|}{$\begin{array}{l}\text { Undergraduate students } \\
\qquad(\mathrm{N}=40)\end{array}$} & \multicolumn{3}{|c|}{$\begin{array}{l}\text { Graduate students } \\
(\mathrm{N}=17)\end{array}$} & \multicolumn{3}{|c|}{ Mean difference } \\
\hline & \multirow{2}{*}{ Mean $\dagger$} & \multicolumn{2}{|c|}{ 95\% C.I. } & \multirow{2}{*}{ Mean $\dagger$} & \multicolumn{2}{|c|}{ 95\% C.I. } & \multirow{2}{*}{ Mean $\dagger$} & \multicolumn{2}{|c|}{ 95\% C.I. } \\
\hline & & Lower & Upper & & Lower & Upper & & Lower & Upper \\
\hline $\begin{array}{l}\text { WebCT vista online } \\
\text { lectures }\end{array}$ & 5.9 & 5.22 & 6.58 & 3.2 & 2.32 & 4.15 & $2.7 * *$ & 1.48 & 3.85 \\
\hline $\begin{array}{l}\text { In-class supplemental } \\
\text { lectures }\end{array}$ & 3.6 & 3.02 & 4.23 & 3.9 & 2.82 & 4.94 & -0.3 & -1.39 & 0.87 \\
\hline $\begin{array}{l}\text { In-class exercise } \\
\text { /practical exam } \\
\text { feedback }\end{array}$ & 4.0 & 3.29 & 4.61 & 5.0 & 3.68 & 6.32 & -1.1 & -2.34 & 0.24 \\
\hline $\begin{array}{l}\text { Help from instructors } \\
\text { in the studio }\end{array}$ & 1.9 & 1.56 & 2.29 & 2.9 & 1.69 & 4.19 & $-1.0 *$ & -1.96 & -0.07 \\
\hline Help from classmates & 2.8 & 2.29 & 3.36 & 4.1 & 2.70 & 5.41 & $-1.2 *$ & -2.39 & -0.08 \\
\hline $\begin{array}{l}\text { Working on homework } \\
\text { assignments }\end{array}$ & 4.8 & 4.19 & 5.36 & 4.4 & 3.31 & 5.40 & 0.4 & -0.68 & 1.52 \\
\hline $\begin{array}{l}\text { Working on exercise } \\
\text { assignments }\end{array}$ & 3.9 & 3.22 & 4.58 & 3.8 & 3.09 & 4.56 & 0.1 & -1.05 & 1.21 \\
\hline Reading the textbook & 6.7 & 6.11 & 7.29 & 6.2 & 4.94 & 7.41 & 0.5 & -0.65 & 1.70 \\
\hline
\end{tabular}

In the 2011 and 2012 surveys, the three learning vehicles (online lectures, help from instructors, and help from classmates) that had a significant difference in the 2003 and 2004 surveys were also ranked similarly (Table 4). However, the mean ranking differences were greater in the 2011 and 2012 surveys than in the previous investigation. While the help from instructors in the studio and from classmates in the 2003 and 2004 surveys showed 1.0 and 1.2 ranking differences between undergraduate and graduate students, respectively, the mean 
ranking differences of the same learning vehicles were 3.4 and 2.1 in the 2011 and 2012 surveys $(p<0.01)$. This means that the undergraduate students in 2011 and 2012 were more likely to rely on help from instructors or classmates rather than individual or independent learning. Further, the in-class Powerpoint lectures assessed in the 2011 and 2012 surveys and the Web CT online lectures in the 2003 and 2004 surveys were more preferred by graduates than undergraduates.

Reading the textbook was ranked low in both groups and in both the 2003-2004 and 20112012 surveys. However, the mean difference for reading the textbook was only significant in the 2011 and 2012 surveys (Diff. = 2.1 higher in graduate students, $\mathrm{p}<0.01$ ), indicating that graduate students preferred reading the textbook more than undergraduate students. It should be noted that reading the textbook in the 2011-2012 surveys was ranked the second lowest by undergraudates. This assignment required independent effort from individuals and very little interactivity among peers and/or with instructors. Undergraduates' dislike of non-interactive learning vehicles was consistent in both the 2003-2004 and 2011-2012 surveys.

Table 4: Descriptive Statistics and Bivariate Analyses of Learning Vehicle Rankings between Undergraduate and Graduate Students in the 2011 and 2012 Surveys

\begin{tabular}{|c|c|c|c|c|c|c|c|c|c|}
\hline \multirow{3}{*}{ Learning vehicles } & \multicolumn{3}{|c|}{$\begin{array}{l}\text { Undergraduate students } \\
\qquad(\mathrm{N}=70)\end{array}$} & \multicolumn{3}{|c|}{$\begin{array}{l}\text { Graduate students } \\
\qquad(\mathrm{N}=39)\end{array}$} & \multicolumn{3}{|c|}{ Mean difference } \\
\hline & \multirow{2}{*}{ Mean $\dagger$} & \multicolumn{2}{|c|}{ 95\% C.I. } & \multirow{2}{*}{ Mean $\dagger$} & \multicolumn{2}{|c|}{ 95\% C.I. } & \multirow{2}{*}{ Mean $\dagger$} & \multicolumn{2}{|c|}{$95 \%$ C.I. } \\
\hline & & Lower & Upper & & Lower & Upper & & Lower & Upper \\
\hline $\begin{array}{l}\text { In-class lectures using } \\
\text { Powerpoint slides }\end{array}$ & 5.7 & 5.00 & 6.46 & 2.3 & 1.57 & 3.04 & $3.4 * *$ & 2.31 & 4.53 \\
\hline $\begin{array}{l}\text { In-class exercise redlinec } \\
\text { feedback using } \\
\text { Powerpoint slides }\end{array}$ & 5.3 & 4.66 & 5.97 & 5.8 & 4.96 & 6.73 & -0.5 & -1.62 & 0.55 \\
\hline $\begin{array}{l}\text { Help from instructors in } \\
\text { the studio }\end{array}$ & 2.9 & 2.40 & 3.34 & 6.3 & 5.35 & 7.27 & $-3.4 * *$ & -4.38 & -2.50 \\
\hline Help from classmates & 5.6 & 4.83 & 6.31 & 7.7 & 6.76 & 8.57 & $-2.1 * *$ & -3.28 & -0.91 \\
\hline $\begin{array}{l}\text { Working on homework } \\
\text { assignments }\end{array}$ & 5.7 & 5.16 & 6.29 & 5.4 & 4.54 & 6.18 & 0.4 & -0.59 & 1.33 \\
\hline $\begin{array}{l}\text { Working on exercise } \\
\text { assignments }\end{array}$ & 4.3 & 3.66 & 4.88 & 3.5 & 2.68 & 4.40 & 0.7 & -0.29 & 1.76 \\
\hline $\begin{array}{l}\text { Working on in-class } \\
\text { assignments }^{\Delta}\end{array}$ & 5.1 & 4.55 & 5.71 & 6.0 & 5.29 & 6.66 & $-0.8 \dagger$ & -1.76 & 0.07 \\
\hline $\begin{array}{l}\text { Demonstration videos } \\
\text { stored in e-learning }\end{array}$ & 5.8 & 4.98 & 6.59 & 5.9 & 4.77 & 7.07 & -0.1 & -1.50 & 1.23 \\
\hline Class Journal $^{\Delta}$ & 10.5 & 10.16 & 10.90 & 9.3 & 8.55 & 10.01 & $1.2 * *$ & 0.52 & 1.97 \\
\hline Reading the textbook & 9.6 & 9.00 & 10.14 & 7.5 & 6.54 & 8.39 & $2.1 * *$ & 1.09 & 3.13 \\
\hline
\end{tabular}

Figures 1(a) and (b) visually show the trends of learning vehicle preferences between undergraduate and graduate students for 20032004 and 2011-2012, respectively. The results of learning vehicle preferences show a similar pattern between the surveys of two investigations. In both investigations, interactive learning vehicles such as help from instructors in the studio and help from classmates were highly preferred by undergraduates, while indepdent learning vehicles such as online lectures and working on homework or exercise assignments were highly preferred by graduates. Further, reading the textbook was ranked low in both groups and in both investigations. 


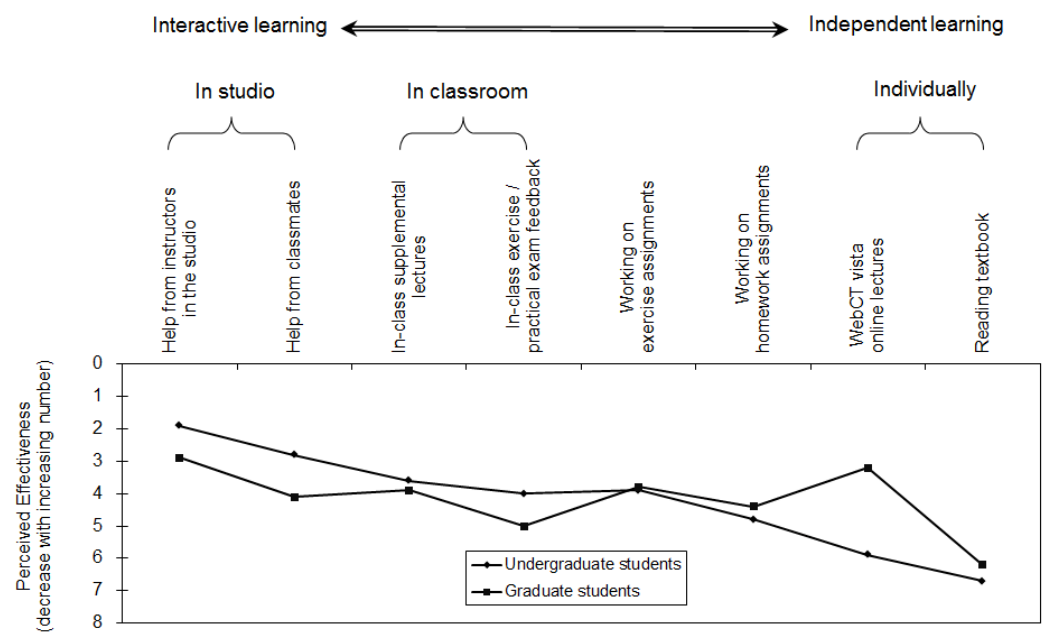

(a) 2003-2004 survey

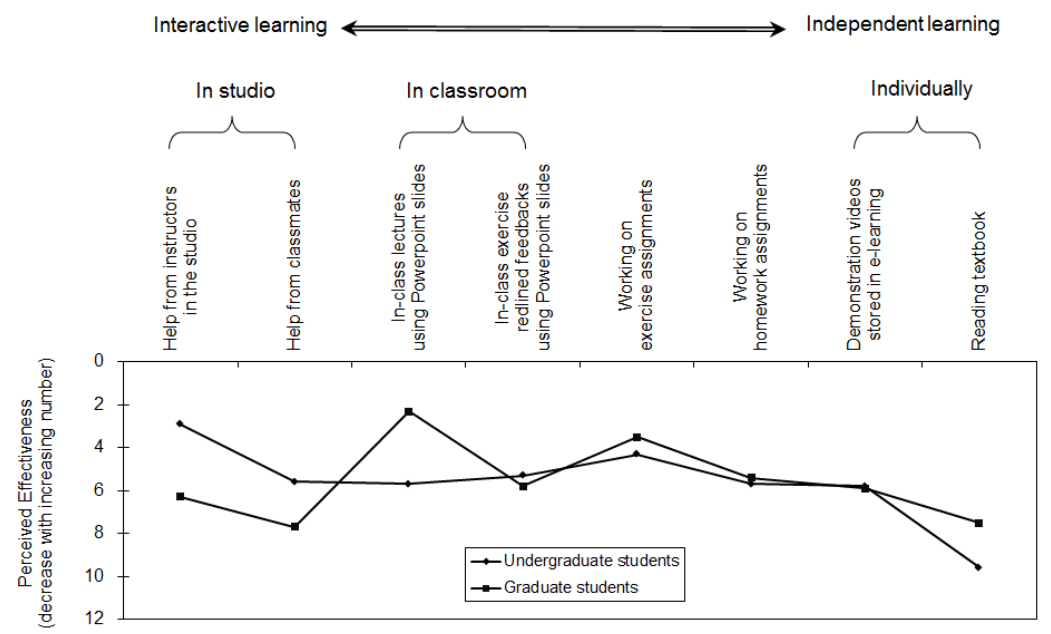

(b) 2011-2012 survey

Figure 1: Trends of Learning Vehicle Preference between the 2003-2004 and 2011-2012 Surveys

\section{Learning Effectiveness by Students' Grade Expectations}

Among students participating in the 2011 and 2012 surveys, a total of 76 students $(63.3 \%)$ expected to receive an $A$ grade in the first survey, while 41 students (34.2\%) expected a B, and 3 students $(2.5 \%)$ expected a $\mathrm{C}$ grade. The grade expectation changed in the second survey. The percentage for an A grade decreased to $38.1 \%$ (44 students), while the expectation for B and C grades increased to $47.8 \%$ (54 students) and $14.2 \%$ (16 students), respectively.

Table 5: Descriptive Statistics and Bivariate Analyses of Learning Vehicle Rankings between Students Expecting an A Grade and a B or C Grade in the 2011 and 2012 surveys

\begin{tabular}{|c|c|c|c|c|c|c|c|c|c|}
\hline \multirow{3}{*}{ Learning vehicles } & \multicolumn{3}{|c|}{$\begin{array}{c}\text { Undergraduate students } \\
(\mathrm{N}=35)\end{array}$} & \multicolumn{3}{|c|}{$\begin{array}{c}\text { Graduate students } \\
(\mathrm{N}=63)\end{array}$} & \multicolumn{3}{|c|}{ Mean difference } \\
\hline & \multirow{2}{*}{ Mean $\dagger$} & \multicolumn{2}{|c|}{ 95\% C.I. } & \multirow{2}{*}{ Meant } & \multicolumn{2}{|c|}{$95 \%$ C.I. } & \multirow{2}{*}{ Mean $\dagger$} & \multicolumn{2}{|c|}{$95 \%$ C.I. } \\
\hline & & Lower & Upper & & Lower & Upper & & Lower & Upper \\
\hline $\begin{array}{l}\text { In-class lectures using } \\
\text { Powerpoint slides }\end{array}$ & 3.1 & 2.10 & 4.19 & 5.3 & 4.54 & 6.10 & $-2.2 * *$ & -3.46 & -0.89 \\
\hline In-class exercise redlinec & 5.5 & 4.54 & 6.37 & 5.6 & 4.88 & 6.32 & -0.1 & -1.32 & 1.03 \\
\hline
\end{tabular}




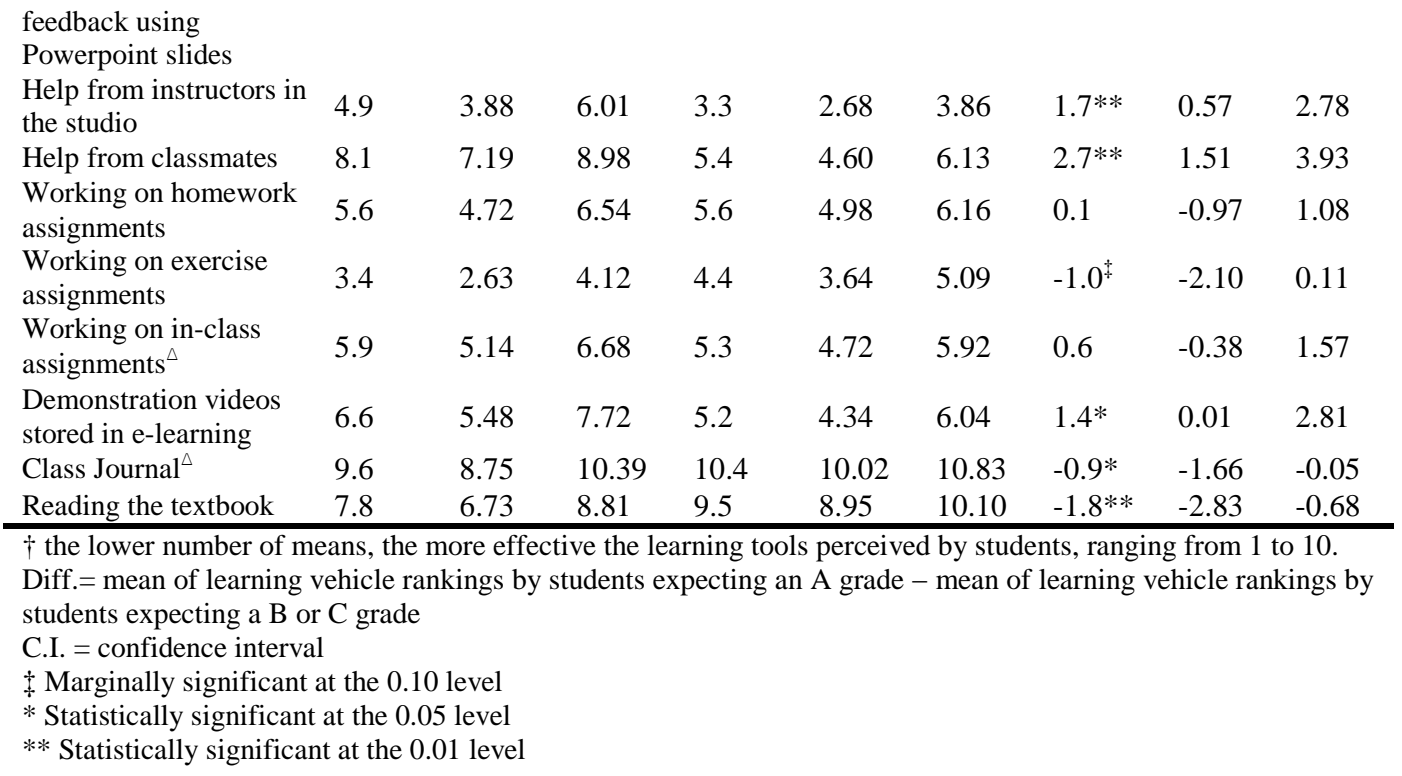

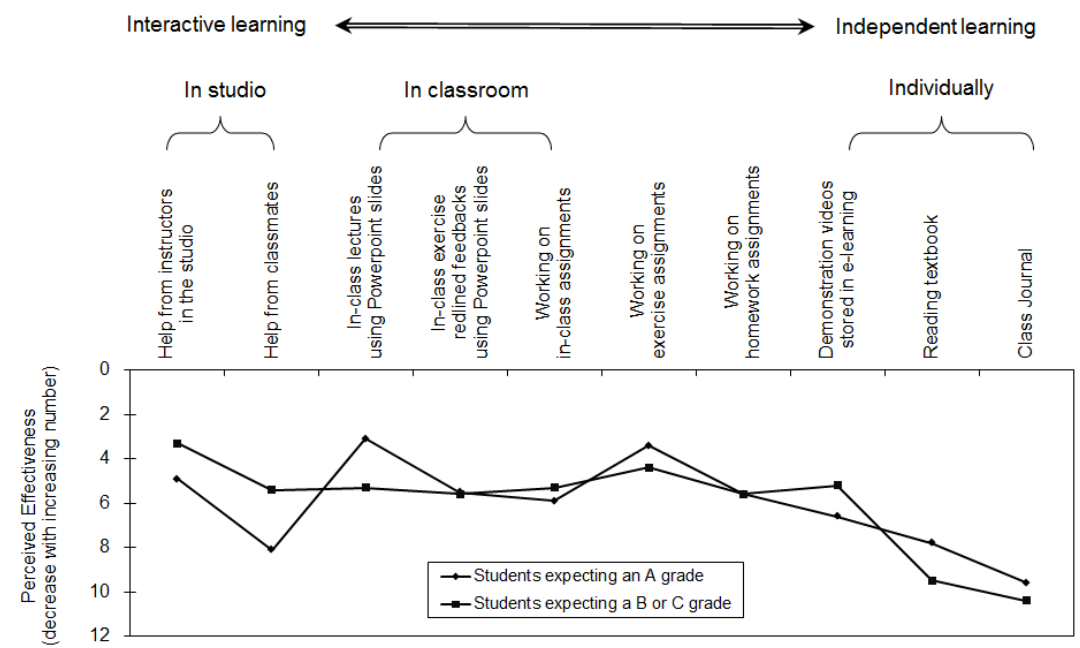

Figure 2: Preferences of Learning Vehicle between Students Expecting an A Grade and a B or C Grade in the 2011 and 2012 Surveys

Table 5 and Figure 2 represent the results of learning preferences between students expecting an A grade and those expecting a B or $C$ grade. Students who expected an A grade were more adaptive to individual learning such as the class journal $(\mathrm{p}<0.05)$ and reading the textbook $(\mathrm{p}<0.01)$ than those expecting a B or $\mathrm{C}$ grade, and were more likely to understand the course subjects by working on exercise assignments independently. The results also show that in-class lectures using Powerpoint slides were more helpful to students expecting an A grade than the group of students expecting a B or $\mathrm{C}$ grade. However, students who expected lower grades tended to prefer more interactive learning methods such as getting help from instructors in the studio or getting help from classmates. Interestingly, pre-recorded demonstration videos that show grading processes stored in e-learning were more efficient for students expecting a $\mathrm{B}$ or $\mathrm{C}$ grade $(\mathrm{p}<0.05)$.

\section{Conclusions}

This study investigated the effectiveness of web-enhanced teaching in landscape construction studio courses taken by both undergraduate and graduate students. The researchers conducted a longitudinal comparison on two investigations that were performed eight years apart. The researchers 
also surveyed students' preferred learning vehicles in both investigations. The result indicates that students were highly satisfied with web-enhanced teaching in both investigations. Particularly, students in recent years were more satisfied with web-enhanced teaching than those in the past. Undergraduate and graduate students preferred different types of learning vehicles, in which undergraduates preferred interactive types. In addition, students expecting an A grade were more likely to prefer individual or independent learning vehicles whereas students expecting a B or $\mathrm{C}$ grade relied on interactive learning methods.

This study provides landscape architecture educators an insight into the opportunities and challenges in applying web-enhanced teaching in studio-based courses. Particularly, findings of the study are useful for those who may use a similar pedagogical approach. The lessons learned from the longitudinal investigations can be described as follows. First, web is no longer an add-on feature in teaching but a necessity. More students enter the colleges and graduate schools without knowing that they have been well adapted to learning from the online environment, i.e., e-learning. Second, the interactivity of e-learning is still not as strong as that of face-to-face meetings. Undergraduates who are more likely to rely on interactive learning may suffer from web-based teaching that often lacks interactive communications. Web-enhanced teaching appears to be a viable option that balances the need of interactivity and accessibility to course materials.

\section{References}

1. ABRAMS, G. \& HAEFNER, J. 2002. Blending online and traditional instruction in the mathematics classroom. The Technology Source Archives.

2. BENBUNAN-FICH, R. 2002. Improving education and training with IT. Communications of the ACM, 45, 94-99.
3. BENDER, D. M. \& VREDEVOOGD, J. D. 2006. Using online education technologies to support studio instruction. JOURNAL OF EDUCATIONAL TECHNOLOGYAND SOCIETY, 9, 114.

4. CHANG, K.-E., SUNG, Y.-T. \& HOU, H.-T. 2006. Web-based tools for designing and developing teaching materials for integration of information technology into instruction. Educational Technology \& Society, 9, 139-149.

5. CHEN, W. \& YOU, M. 2010. Student response to an Internet-mediated industrial design studio course. International Journal of Technology and Design Education, 20, 151-174.

6. DZIUBAN, C. \& MOSKAL, P. 2001. Evaluating the Impact of a Distributed Learning Program [Online]. Available: http://www.tltgroup.org/resources/F_Eval_Cas es/UCF_DistribLearn.htm [Accessed May 15, 2013.

7. JONASSON, J. 1997. The Internet-the Educational Medium of Today. Educational Media International, 34, 88-93.

8. LI, M. H. 2007. Lessons Learned from WebEnhanced Teaching in Landscape Architecture Studios. International Journal on E-Learning, 6, 205-212.

9. MATTHEWS, D. \& WEIGAND, J. 2001. Collaborative design using the internet: A case study. Journal of Interior Design, 27, 45-53.

10.SALOMONI, P. \& MIRRI, S. A multimedia broker for ubiquitous and accessible rich media content transcoding. Global Telecommunications Conference Workshops, 2004. GlobeCom Workshops 2004. IEEE, 2004. IEEE, 186-191.

11.SCANLON, E., JONES, A., BARNARD, J., THOMPSON, J. \& CALDER, J. 2000. Evaluating information and communication technologies for learning. Educational Technology \& Society, 3, 101-107. 